\title{
Homogenitas Ketebalan, Konduktivitas Listrik dan Band Gap Lapisan Tipis a-Si:H tipe-p dan tipe-p Doping Delta yang dideposisi dengan Sistem PECVD
}

\author{
Enny Kusumawati* dan Eddy Yahya \\ Jurusan Fisika-FMIPA, Institut Teknologi Sepuluh Nopember \\ Kampus ITS Sukolilo, Surabaya 61111
}

\begin{abstract}
Intisari
Telah berhasil dideposisi lapisan tipis a-Si:H tipe p-biasa dan tipe p-delta menggunakan PECVD dengan pada temperatur $270^{\circ} \mathrm{C}$, tekanan $530 \mathrm{mTorr}$, Laju gas $\mathrm{SiH} 4=20 \mathrm{sccm}, \mathrm{H} 2=70 \mathrm{sccm}, \mathrm{B} 2 \mathrm{H} 6=2 \mathrm{sccm}$. Lapisan pdelta berstruktur p-i-p menghasilkan ketebalan rata-rata p-delta 198,7 nm dan rata-rata p-tipis $89,7 \mathrm{~nm}$. Sampel dibiarkan dalam ruangan terbuka sehingga warna permukaan sampel tidak homogen. Ketidak-homogenan sampel diuji melalui ketebalan menggunakan ellipsometer dan diamati perubahan band gap menggunakan UV-Vis serta pengukuran konduktivitas dengan metode coplanar kemudian dilihat perbandingan kedua besaran tersebut pada lapisan p-biasa dengan p-delta. Hasilnya, ketebalan lapisan p-biasa cenderung homogen yakni 98,8nm, sedangkan lapisan p-delta bervariasi antara 165,1 - 219,7 nm. Pengukuran band gap cenderung homogen dengan nilai tertinggi 1,60 eV untuk tipe p-biasa dan 1,74 eV untuk tipe p-delta. Pengukuran konduktivitas listrik juga cenderung homogen dengan konduktivitas tertinggi saat gelap dan saat terang berturut-turut $0,71 \mathrm{~S} / \mathrm{cm}$ dan $1,01 \mathrm{~S} / \mathrm{cm}$ untuk struktur p-biasa serta $0.39 \mathrm{~S} / \mathrm{cm}$ dan $0,35 \mathrm{~S} / \mathrm{cm}$ untuk struktur p-delta.
\end{abstract}

KATA KUNCI: struktur p-delta, PECVD, ketebalan lapisan, band gap

\section{PENDAHULUAN}

Lapisan-p pada sel surya $\mathrm{p}-\mathrm{i}-\mathrm{n}$ a-Si:H sangat berpengaruh terhadap efisiensi karena berfungsi sebagai lapisan depan penerima cahaya. Sebagai lapisan penerima cahaya, lapisan$\mathrm{p}$ harus bersifat transparan sehingga foton yang masuk semakin banyak, yang berarti konsentrasi pembawa meningkat. Agar lapisan-p bersifat transparan dan mampu meningkatkan konsentrasi pembawa muatan, ditambahkan lapisan-i pada tengah-tengah lapisan-p yang dibuat lebih tipis [1]. Struktur baru ini dikenal dengan doping delta lapisan-p atau biasa disebut lapisan p-delta. Dengan ditambahkannya lapisan-i pada tengah-tengah lapisan-p tipis, dangling bond semakin berkurang dan lapisan menjadi lebih transparan sehingga prosentase foton yang sampai pada lapisan intrinsik meningkat. Skema lapisan tipis a-Si:H tipe-p dengan doping delta tampak pada Gambar 1.

Ketahanan lapisan tipis terhadap perubahan pengaruh lingkungan luar juga merupakan hal penting untuk diteliti pengaruhnya. Pada kenyataannya warna lapisan tipis berubah

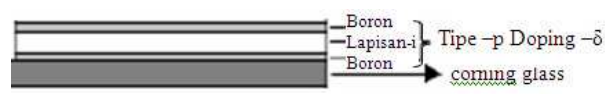

Gambar 1: Lapisan P-Delta di Atas Substrat Corning Glass

\footnotetext{
*E-MAIL: enny09@mhs.physics.its.ac.id
}

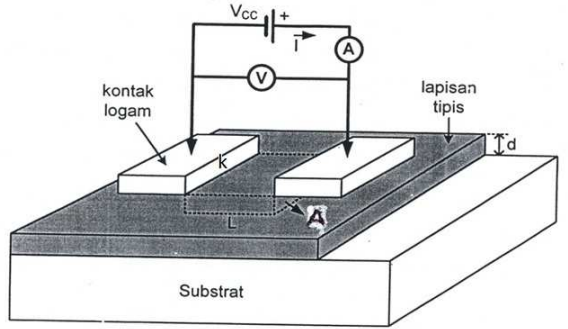

Gambar 2: Skema Pengukuran Konduktivitas Dengan Metode Coplanar

setelah sampel diletakkan di ruang terbuka. Diduga perubahan sampel juga diikuti dengan perubahan ketebalan lapisan, band gap dan konduktivitas bahan. Oleh karena itu perlu diteliti lebih lanjut tentang pengaruh perubahan fisik yang tampak pada lapisan tipis terhadap band gap dan konduktivitas lapisan a-Si:H tipe p-biasa dan tipe-p delta hasil deposisi PECVD.

Pengukuran konduktivitas dengan metode coplanar dapat ditentukan dengan persamaan:

$$
\sigma_{d}=\frac{I}{V} \frac{L}{k d}
$$

dengan $\mathrm{V}$ adalah tegangan yang diberikan, I adalah kuat arus, $\mathrm{L}$ adalah jarak antara elektrode, $\mathrm{k}$ adalah panjang elektrode dan d adalah ketebalan lapisan tipis. Skema pengukuran dengan metode coplanar dapat dilihat pada Gambar 2.

Transparansi suatu lapisan dapat digambarkan secara kuantitatif dengan besarnya celah pita energi lapisan tersebut. Metode perhitungan celah pita energi lapisan a-Si:H den- 


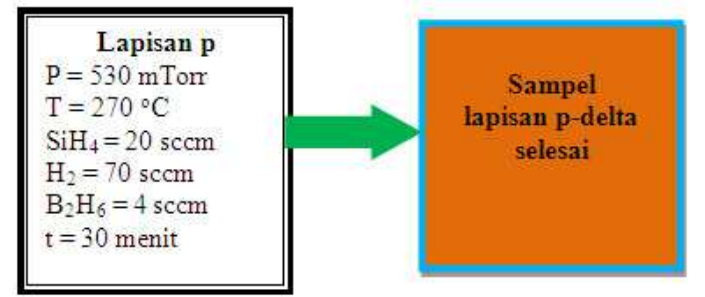

Gambar 3: Proses Deposisi Lapisan a-S:H Tipe p-Biasa

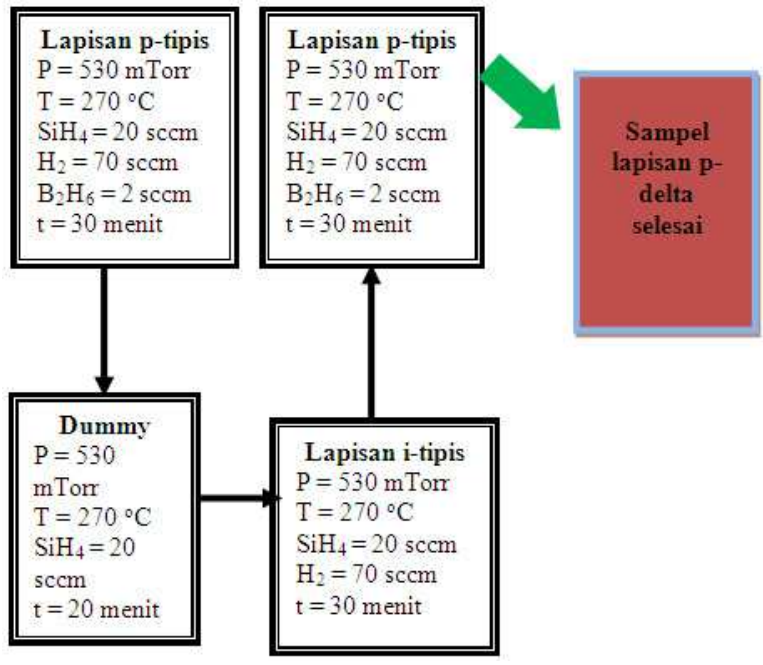

Gambar 4: Proses Deposisi Lapisan a-Si:H Tipe p-Delta

gan metode Touch Plot dengan cara menarik garis secara ekstrapolasi pada daerah linier dari grafik hubungan antara dengan hingga memotong sumbu energi [2]. Perpotongan hasil ekstrapolasi dengan sumbu energi inilah yang menunjukkan celah pita optik.

\section{EKSPERIMEN}

Tahap awal pembuatan sampel adalah mempersiapkan substrat corning eagle yaitu dipotong $10 \times 10 \mathrm{~cm}^{2}$ dan dibersihkan dengan alkohol. Pada Gambar 3 dan 4, variabel deposisi meliputi tekanan, laju gas, dan temperatur diinput pada panel kontrol, selanjutnya sampel dimasukkan dalam chamber. Pada lapisan tipe p-biasa, sampel hanya masuk PL3 sebanyak satu kali. Sedangkan untuk lapian p-delta, setelah deposisi lapisan $\mathrm{p}$, sampel harus dikeluarkan dari PL3 untuk menghindari kontaminasi pengotor pada deposisi lapisan intrinsik dengan didummy [3]. Saat sampel dikeluarkan dari PL3, PL3 dilapisi dengan lapisan intrinsik dengan mengalirkan gas silan.

Setelah sampel lapisan a-Si:H tipe p-biasa dan tipe p-delta selesai, sampel disimpan dalam ruangan terbuka sehingga terjadi perubahan kehomogenan warna pada permukaan sampel. Setiap daerah yang berbeda warna dicuplik untuk diukur ketebalannya dengan ellipsometer. Gambar perubahan warna pada serta pemilihan daerah cuplikan tampak pada Gambar 5.

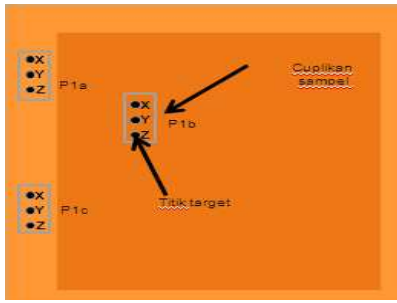

(a)Lapisan p-Biasa

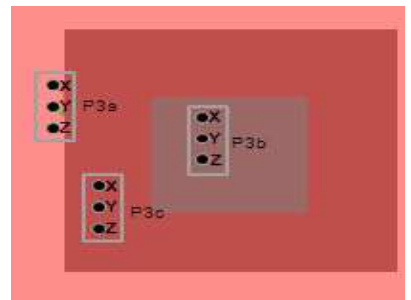

(b)Lapisan p-Delta
Gambar 5: Perubahan Warna Lapisan Serta Pemilihan Daerah Cuplikan.

TABEL I: Sampel Lapisan Tipis Tipe P-Biasa, Sudut $70^{\circ}$, Waktu Deposisi Lapisan P 30 Menit

\begin{tabular}{|c|c|c|c|c|}
\hline \multirow[t]{2}{*}{ No. } & \multirow[t]{2}{*}{ Target } & \multicolumn{3}{|c|}{$\begin{array}{c}\text { Ketebalan cuplikan } \\
\text { sampel(nm) }\end{array}$} \\
\hline & & P1a & P1b & P1c \\
\hline 1 & $\mathrm{X}$ & 98,7 & 98,7 & 98,7 \\
\hline 2 & $Y$ & 98,8 & 98,7 & 98,7 \\
\hline 3 & $\mathrm{Z}$ & 99,0 & 98,5 & 98,8 \\
\hline rata-rata & & 98,8 & 98,6 & 98,7 \\
\hline
\end{tabular}

Sampel dikarakterisasi dengan metode coplanar untuk menentukan konduktivitas listrik di setiap titik target pada cuplikan sampel seperti tampak pada Gambar 5. Penentuan band gap menggunakan data absorbansi spektrometer UV-Vis dengan panjang gelombang 200-900 $\mathrm{nm}$.

\section{HASIL DAN PEMBAHASAN}

Pada Tabel I terlihat lapisan-p a-Si:H memiliki ketebalan rata-rata sekitar $9.87 \times 10^{-6} \mathrm{~cm}$. Sedangkan pada Tabel II menunjukkan variasi perbedaan ketebalan yang cukup besar dengan selisih $\approx 20-30 \mathrm{~nm}$.

Sesuai pengamatan dengan mata telanjang dan melalui pengukuran manual bahwa lapisan p-biasa memiliki kehomogenan warna permukaan $80 \%$ dari luas sampel sedangkan lapisan p-delta sekitar $30 \%$ dari luas sampel. Hal ini diduga terjadi karena proses deposisi pada lapisan-p delta yang keluar-masuk PL3 sebanyak tiga kali sehingga kuat ikatan pada daerah interface mudah rusak yang ditandai dengan degradasi warna setelah sampel diletakkan di ruang terbuka. Selain itu degradasi warna dimulai dari bagian tepi sam-

TABEL II: Sampel Lapisan Tipis Tipe p-Delta, Sudut $70^{\circ}$, Waktu Deposisi Lapisan p-Tipis 10 menit, Lapisan-i Tipis 30 menit

\begin{tabular}{|c|c|c|c|c|}
\hline \multirow[t]{2}{*}{ No. } & \multirow[t]{2}{*}{ Target } & \multicolumn{3}{|c|}{$\begin{array}{l}\text { Ketebalan cuplikan } \\
\text { sampel(nm) }\end{array}$} \\
\hline & & P3a & $\mathrm{P} 3 \mathrm{~b}$ & $\mathrm{P} 3 \mathrm{c}$ \\
\hline 1 & $\mathrm{X}$ & 159,0 & 219,8 & 167,9 \\
\hline 2 & Y & 219,0 & 220,0 & 162,0 \\
\hline 3 & $\mathrm{Z}$ & 218,0 & 220,0 & 165,0 \\
\hline rata-rata & & 198,7 & 219,7 & 165,1 \\
\hline
\end{tabular}


TABEL III: Hasil Perhitungan Konduktivitas Gelap dan Fotokonduktivitas Lapisan Tipis a-Si:H Tipe p-Biasa

\begin{tabular}{lcccccc}
\hline Variabel & \multicolumn{3}{c}{ P1a } & \multicolumn{2}{c}{ P1b } & \multicolumn{2}{c}{ P1c } \\
Terkait & Gelap & Terang & Gelap & Terang & Gelap & Terang \\
\hline$\frac{1}{R}\left(\times 10^{-7}\right)$ & 0,88 & 1,93 & 4,75 & 5,38 & 7,00 & 10,00 \\
$\mathrm{R}\left(\Omega \times 10^{6}\right)$ & 11,40 & 5,18 & 2,11 & 1,86 & 1,43 & 1,00 \\
Tebal lapisan & 98,8 & 98,8 & 98,0 & 98,0 & 98,7 & 98,7 \\
diameter $(\mathrm{cm})$ & 0,1 & 0,1 & 0,1 & 0,1 & 0,1 & 0,1 \\
$\mathrm{~A}\left(\times 10^{-7} \mathrm{~cm}^{2}\right)$ & 9,88 & 9,88 & 9,80 & 9,80 & 9,87 & 9,87 \\
$\mathrm{~L}(\mathrm{~cm})$ & 1 & 1 & 1 & 1 & 1 & 1 \\
resistivitas $(\Omega . \mathrm{cm})$ & 11,20 & 5,12 & 2,06 & 1,82 & 1,41 & 0,99 \\
Konduktivitas $\left(\times 10^{-2} \mathrm{~S} / \mathrm{cm}\right)$ & 8,9 & 19,5 & 48,5 & 54,9 & 70,9 & 101,0 \\
\hline \hline
\end{tabular}

TABEL IV: Hasil perhitungan Konduktivitas Gelap dan Fotokonduktivitas Lapisan Tipis a-Si:H Tipe p-Delta

\begin{tabular}{|c|c|c|c|c|c|c|}
\hline \multirow{2}{*}{$\begin{array}{l}\text { Variabel } \\
\text { Terkait }\end{array}$} & \multicolumn{2}{|c|}{ P3a } & \multicolumn{2}{|c|}{$\mathrm{P} 3 \mathrm{~b}$} & \multicolumn{2}{|c|}{$\mathrm{P} 3 \mathrm{c}$} \\
\hline & Gelap & Terang & Gelap & Terang & Gelap & Terang \\
\hline$\frac{1}{R}\left(\times 10^{-7}\right)$ & 8,37 & 82,9 & 5,68 & 73,20 & 2,00 & 6,00 \\
\hline $\mathrm{R}\left(\Omega \times 10^{6}\right)$ & 1,20 & 12,10 & 1,76 & 1,37 & 5,00 & 1,67 \\
\hline tebal lapisan (nm) & 215,0 & 215,0 & 220,0 & 220,0 & 160,0 & 160,0 \\
\hline diameter $(\mathrm{cm})$ & 0,1 & 0,1 & 0,1 & 0,1 & 0,1 & 0,1 \\
\hline $\mathrm{A}\left(\times 10^{-7} \mathrm{~cm}^{2}\right)$ & 2,15 & 2,15 & 2,20 & 2,20 & 1,60 & 1,60 \\
\hline $\mathrm{L}(\mathrm{cm})$ & 1 & 1 & 1 & 1 & 1 & 1 \\
\hline resistivitas $(\Omega . c$ & 2,57 & 0,26 & 3,87 & 3,01 & 8,00 & 2,67 \\
\hline konduktivitas $\left.\left(\times 10^{-2} \mathrm{~S} / \mathrm{cm}\right)\right)$ & 39 & 386 & 26 & 33 & 13 & 36 \\
\hline
\end{tabular}

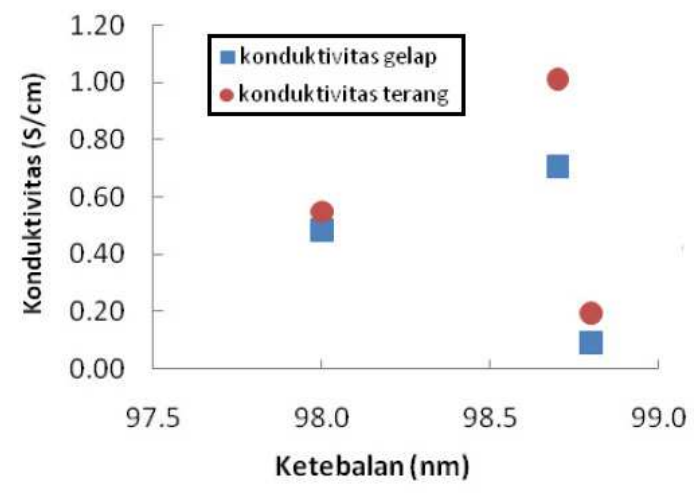

Gambar 6: Variasi Konduktivitas terhadap Ketebalan pada Lapisan Tipis Tipe p-Biasa

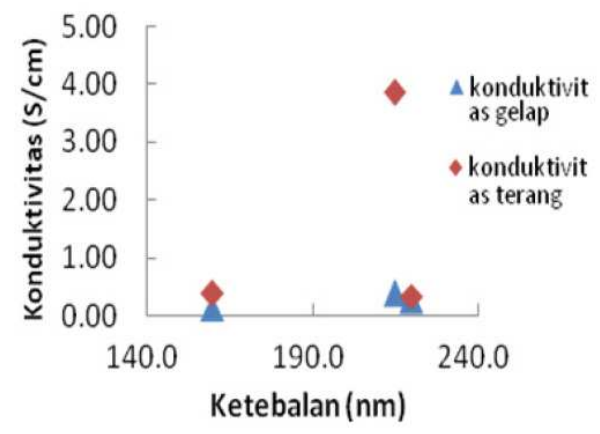

Gambar 7: Variasi Konduktivitas terhadap Ketebalan pada Lapisan Tipis Tipe p-Delta pel dimana kontak lapisan pada bagian tepi dengan lingkungan luar semakin besar. Akibatnya reaksi kimia dengan lingkungan sekitar lebih cepat terjadi pada daerah tepi. Selain faktor teknis keluar-masuk PL3, kualitas mesin PECVD juga berpengaruh besar terhadap ketebalan lapisan yang dihasilkan. Hal ini ditandai dengan waktu penumbuhan lapisan p-tipis awal dan p-tipis akhir sama yaitu 30 menit, tapi terdapat selisih ketebalan 23,6 nm. Hal tersebut dapat disebabkan oleh plasma yang muncul-hilang-muncul-hilang selama proses deposisi, sehingga laju penumbuhan lapisan tidak stabil. Data ketebalan lapisan selanjutnya digunakan untuk menghitung band gap dan konduktivitas lapisan tipis.

Pengukuran konduktivitas dilakukan pada temperatur ruang $25^{\circ} \mathrm{C}$ dengan penerangan $2080 \mathrm{watt} / \mathrm{m}^{2}$ sebagai sumber cahaya untuk mendapatkan konduktivitas terang. Masingmasing sampel dilakukan pengukuran I-V sebanyak 3 kali pada titik target X, Y dan Z. Hasil pengukuran I-V diplotkan sehingga diperoleh kemiringan grafik sebagai nilai $\frac{1}{R}$.

Tabel III dan IV menunjukkan nilai $\frac{1}{R}$ yang digunakan untuk menghitung nilai konduktivitas lapisan tipis tipe pbiasa dan tipe p-delta. Terlihat bahwa fotokonduktivitas lebih tinggi dari konduktivitas gelap. Hal ini terjadi karena pada saat penyinaran elektron mendapatkan energi yang digunakan bergerak menuju pita konduksi sehingga terjadi pasangan hole-elektron [4].

Nilai konduktivitas gelap lapisan tipis P1a, P1b, dan P1c bervariasi disebabkan nilai resistivitas bahan yang bervariasi. Dari segi ketebalan yang relativ sama $(98,7 \mathrm{~nm})$ ternyata menghasilkan konduktivitas yang berbeda. Hal ini menunjukkan bahwa nilai konduktivias jenis suatu bahan tidak dipengaruhi oleh faktor ketebalan, melainkan dipengaruhi jenis bahan penyusunnya. Begitu pula dengan kehomogenan 


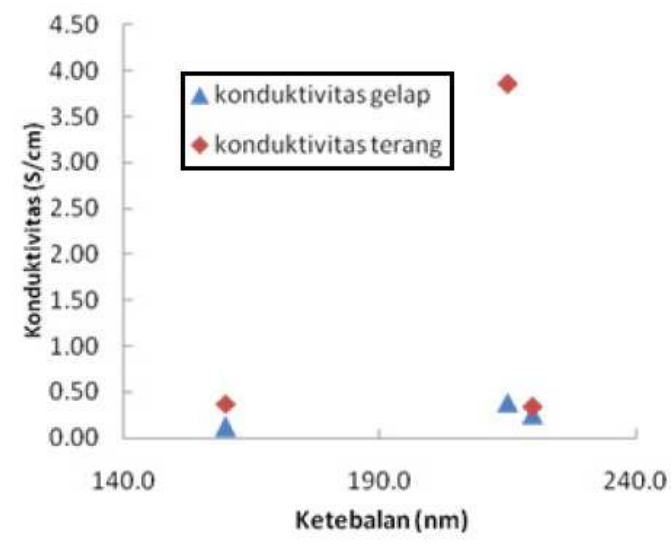

(a)Tipe p-Biasa

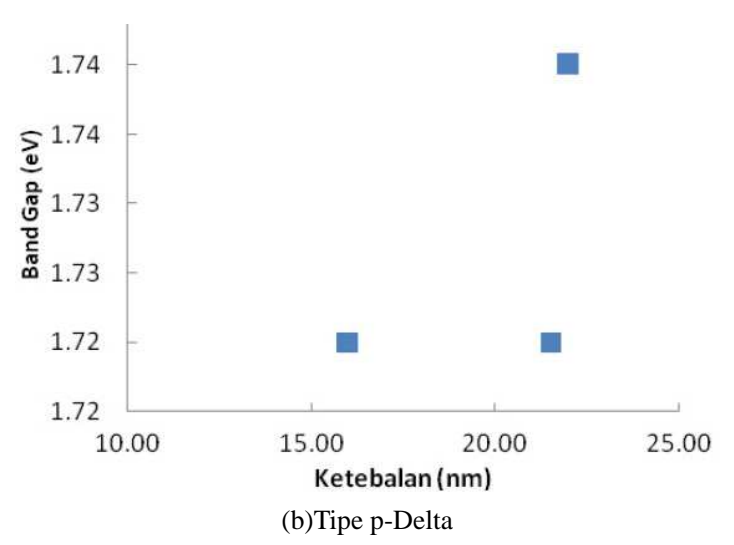

(b)Tipe p-Delta

Gambar 8: Pengaruh Ketebalan terhadap band gap Lapisan tipis a-Si:H.

TABEL V: Hasil Perhitungan Bandgap Lapisan Tipis Tipe p-Biasa

\begin{tabular}{cccc}
\hline \hline Variabel & P1a & P1b & P1c \\
\hline Tebal lapisan $(\mathrm{nm})$ & 98,8 & 98,0 & 98,7 \\
band gap $(\mathrm{eV})$ & 1,5 & 1,6 & 1,6 \\
\hline \hline
\end{tabular}

TABEL VI: Hasil Perhitungan Bandgap Lapisan Tipis Tipe p-Delta

\begin{tabular}{cccc}
\hline \hline Variabel & P3a & P3b & P3c \\
\hline Tebal lapisan $(\mathrm{nm})$ & 215,0 & 220,0 & 160,0 \\
Band gap (eV) & 1,72 & 1,74 & 1,72 \\
\hline \hline
\end{tabular}

warna kepekatan permukaan mencapai $80 \%$ untuk lapisan tipis-p biasa. Nilai konduktivitas lapisan-p doping delta tidak signifikan dengan perbedaan ketebalan.

Bila diplotkan data konduktivitas versus ketebalan akan terlihat seperti pada Gambar 6 untuk lapisan tipe p-biasa dan Gambar 7 untuk tipe p-delta. Dari Gambar 6, perubahan ketebalan diikuti dengan perubahan konduktivitas. Namun peningkatan ketebalan tidak sebanding dengan peningkatan konduktivitas. Ketebalan tidak berpengaruh besar terhadap konduktivitas lapisan. Begitupun dengan lapisan tipe p-delta. Konduktivitas tertinggi tipe p-biasa terdapat pada ketebalan 98,7 $\mathrm{nm}$ dan tipe p-delta $215,0 \mathrm{~nm}$.

Hasil analisis spektrometer UV-Vis dapat diperoleh nilai band gap dengan metode Tauch Plot. Tabel V dan VI menunjukkan nilai ketebalan lapisan versus band gap. Tabel $\mathrm{V}$ dan VI menunjukkan nilai band gap yang stabil terhadap perubahan ketebalan lapisan. Lebih jelas terlihat pada Gambar 8. Dari Tabel V dan VI serta Gambar 8 terlihat ketebalan lapisan p-biasa dengan lapisan p-delta tidak berpengaruh secara signifikan terhadap nilai band gap lapisan. Pada lapisan intrinsik, ketebalan lapisan sebanding dengan besar absorbsi [5]. Berbeda dengan lapisan a-Si:H yang diberi pengotor. Ketebalan tidak berpengaruh besar terhadap nilai absorbsi dan band gap. Hal ini dikarenakan lapisan p adalah lapisan mati sedangkan lapisan intrinsik adalah lapisan aktif [6] lapisan intrinsik bertindak sebagai daerah deplesi.

\section{SIMPULAN}

Berdasarkan penelitian yang telah dilakukan dapat ditarik kesimpulan bahwa homogenitas ketebalan lapisan p-biasa relativ homogen, rata-rata $98,7 \mathrm{~nm}$. Konduktivitas lapisan pbiasa bervariasi yaitu 0,$08 ; 0.49$ dan $0,71 \mathrm{~S} / \mathrm{cm}$ pada saat gelap dan 0,$20 ; 0,55$ dan $1,01 \mathrm{~S} / \mathrm{cm}$ pada saat terang, dapat disebabkan dari faktor pengukuran dengan I-V meter. Nilai band gap lapisan lapisan p-biasa relativ homogen yaitu 1,5; 1,6 dan 1,6 eV. Homogenitas ketebalan lapisan p-biasa bervariasi yaitu 198,7; 165.1dan19,7 nm.Konduktivitas lapisan p-delta bervariasi yaitu 0,$39 ; 0,26$ dan $0,13 \mathrm{~S} / \mathrm{cm}$ pada saat gelap dan 3,$86 ; 0,33$ dan $0,36 \mathrm{~S} / \mathrm{cm}$ pada saat terang. Nilai band gap lapisan lapisan p-biasa reltiv homogen yaitu 1,72; 1,72 dan $1,74 \mathrm{eV}$. Konduktivitas lapisan $\mathrm{p}$ lebih tinggi dibandingkan konduktivitas lapisan p-delta.band gap lapisan p-delta lebih besar dibandingkan lapisan p-biasa.Lapisan p-delta berpotensi untuk digunakan sebagai lapisan muka sel surya p-i-n a-Si:H karena konduktivitas rata-rata yang lebih kecil yaitu $0,26 \mathrm{~S} / \mathrm{cm}$ dan band gap yang lebih lebar yaitu $1,73 \mathrm{eV}$.
[1] Supu, A., Jurnal Kontribusi Fisika Indonesia, Vol 12 No. 3, hal 75-80 (2001).

[2] Malago, J.D., Jurnal Aplikasi Fisika, Vol 5, No.1, hal 14-21 (2009).
[3] Kolobov, A. V., Photo-Induced Metastability in Amorphous Semoconductors ( Weinheim, WILEY-VCH GmbH \& Co. KgaA., 2003) 
[4] Yahya, E., Pembuatan Sel Surya Lapisan Tipis a-Si:H Struktur p-i-n dengan Plasma Chemical Vapor Deposition (PECVD), Laporan Penelitian Hibah Bersaing X/2 perguruan Tinggi Tahun Anggaran 2003, Institut Teknologi Sepuluh Nopember, Surabaya, 2003.

[5] Poortsmans, J. \& Vlaadimir, A. , Thin Film Solar Cells: fabri- cation, Characterization and Aplications (John Wiley \& Sons, 2006).

[6] Takahashi, K. \& Konagai, M., Amorphous Silicon Solar Cells (North Oxford Academic, 1986) 